\title{
Ethnobotany Survey of Medicinal Plants Used for Traditional Maternal Healthcare by Serawai Tribe, Seluma District, Bengkulu - Indonesia
}

\author{
Sri Endarti Rahayu ${ }^{\star, \dagger, 1}$, Rika Oktapianti $^{1}$ Ikhsan Matondang ${ }^{1}$ \\ ${ }^{1}$ Biology Faculty, Universitas Nasional, Jl. Sawo Manila No. 61, Pasar Minggu, Jakarta Selatan 12520, Indonesia.
}

ODOI: https://doi.org/10.15520/jcmro.v3i04.275

Accepted 16-04-2020; Received 01-03-2020; Publish Online 17-04-2020

\author{
Reviewed By: \\ Dr. Songul Budak \\ Diler Department: \\ Reviewer/CMRO
}

\begin{abstract}
Background and objective: Ethnomedicine plays an important role in the maternal healthcare practice of the Serawai tribe of Seluma district, Bengkulu, however, its use has never been documented. This study, therefore, conducts an ethnobotanical survey to document the medicinal plant used for traditional maternal healthcare in the Serawai tribe.

Materials and Methods: The indigenous knowledge was gathered through interaction and questioners with traditional healers.

Results: The study provide information on 52 species belonging to 33 different families. Most of the reported plants belong to Zingiberaceae (13.5\%), Euphorbiaceae, and Poaceae $(5.8 \%)$. The result of life form analyses showed that herb constituted the highest proportion of medicinal plants $(42.3 \%)$, followed by the tree $(25 \%)$, with leaves $(50.9 \%)$ as the most utilized plant parts for preparation of traditional herbal medicines. Approximately $80 \%$ of plant material are found in the surrounding village, with herbal remedies mostly prepared in the form of decoction $(57.7 \%)$ and orally administered. However, among the 16 categories of diseases a total of 8 species were affected by excessive bleeding.

Conclusion: The result showed that medicinal plants had played significant roles in the management of maternal healthcare. The constraints associated with the use of this medical treatment process, is the poor interest of the younger generation in carrying out this tradition. This, has therefore, lead to a significant threat to medicinal plants. It is, therefore, necessary to preserve the indigenous knowledge on traditional medicine by proper documentation, identification of plant species used, and herbal preparation for future usage.
\end{abstract}

Key words: Ethnobotany-Maternal health-Medicinal plants-Serawai tribeIndonesia

\section{INTRODUCTION:}

Over $60 \%$ of the world's population, still recognize traditional medicine as the preferred primary healthcare system, approximately $80 \%$ of developing countries directly depend on medicinal plants for health related-purposes [1]. In Indonesia, ethnomedicine has been practiced for a millennium, with significant contributions added over the years by indigenous healers that used medicinal plant, however, it is

* Corresponding author.

† Email: sriendartirahayu@gmail.com currently used by Primary Health Care (PHC) at the community level $[2]^{2}$.

Indonesia has a large biodiversity of plants with approximately 30,000-50,000 different species, however, only 7500 species are used as drug ingredient (LIPI 2015). The use of medicinal plants has been discovered to be used in the treatment of several diseases and health conditions, including maternal disorders, which is considered an important public and social health problem [2]. Subsequently, the rate of maternal mortality in Indonesia is 228 per 100,000 birth, and this is considerably higher when compared to India (62) and Netherlands (6) [3]. This unprecedented figure tends not to 
be disassociated from the fact that most Indonesian women employ the services of Traditional irth Attendants (TBSs) and Traditional Healers (THs). The local healers and traditional birth attendants are referred to as "dukun" and "dukun bayi" in the local Indonesian language [4]. Dukun and dukun bayi continue to play an important role in maternal healthcare, particularly in rural areas. In the Serawai tribe in Seluma district, Bengkulu, these healers are perceived as an alternative to community healthcare center [5]

Generally, the knowledge of ethnomedicine is orally transmitted by individuals, families, or the community from one generation to the next [6], and most of these teachings have not been formally documented [7]. However, in recent years, there has been a continuous decline in traditional medical practices because the younger generation shows few interest. Therefore, this study aims to document plants traditionally used for the treatment of maternal disorders by the Serawai tribe of Seluma district, Bengkulu, Indonesia.

\section{MATERIALS AND METHODS:}

Description of the study area

This study was conducted in Seluma district, Bengkulu, which lies at a latitude of $4^{\circ} 06$ '23" Southwards and longitude of $102^{\circ 3} 6$ ' 18 " Eastwards. It is located $78,4 \mathrm{~km}$ from Bengkulu city and cover an area of $2.400 .44 \mathrm{~km}^{2}$.

The average temperature is $24^{\circ} \mathrm{C}$, with a mean annual rainfall of $225 \mathrm{~mm}$ [8]. Furthermore, a census survey conducted in 2010 showed that the Talo district had a total population of 10.591. The inhabitant are mostly indigenous, and the majority are Muslims in possession of their script, known as "Surat Ulu" [9]. In addition, their economy is predominantly dependent on agriculture, mainly coffee and clove plantation .

Furthermore, rural areas were selected due to poor infrastructure in the urban region. They also suffer high levels of poverty due to a lack of appropriate income [10]. These factors urge people to indulge in traditional medicine for maternal healthcare and tend to preserve their indigenous knowledge.

\section{Ethnobotanical data collection}

Ethnobotanical data were collected by interviewing a total of 35 respondents on the indigenous knowledge of medicinal plants used for maternal healthcare, with proper documentation on the harvested products. These respondents consisting of 15 males and 20 females, were selected using the purposive sampling method [11]. The respondents were well-known in the community due to their long practice in providing services related to traditional maternal healthcare. They consist of conventional healers between 19 to 68 years while the rest were elders who had acquired knowledge on the medicinal importance of plant from parents and relatives that used it in the past.

Furthermore, both informal and formal conversations, discussion, and semi-structured interview, as well as visits to the field, were conducted. A series of individual interviews were carried out to acquire information con-

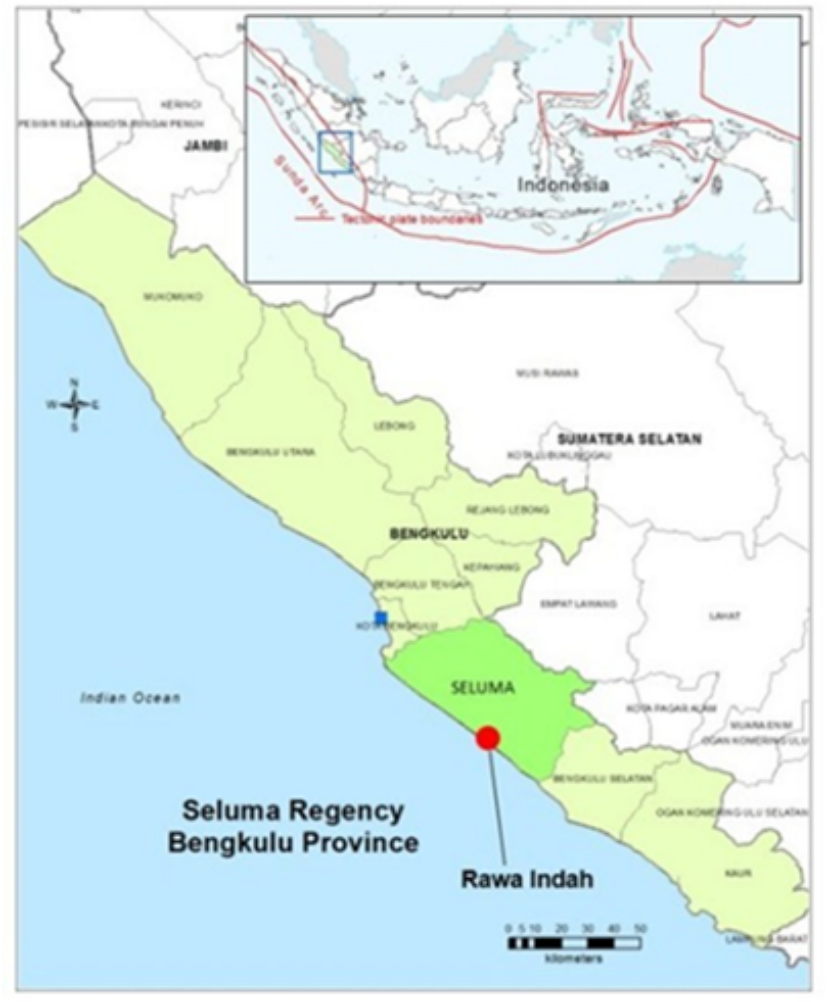

Figure 1. Map of Selumadistrict, Bengkulu.

cerning name, age, sex, level of education, and occupation. Additionally, respondents were interviewed on the local names of medicinal plants, use, type of management (wild/cultivated), and maternal health conditions. They were also asked whether a combination of individual species of plants are used to treat any particular disease, the preparation method and routes of administration. Semistructured questionnaires were also used to collect data on life form from tree, shrub, herb , climbers, and traditional conservation practices of the reported medicinal plant. All the semi-structured reviews were supported by an independence visit to the field, which offered opportunities for more discussions with the respondents and practical identification of traditionally used medicinal plant in their natural environment. However, o plant samples were collected, while interview and discussion were conducted in local language .

\section{RESULT AND DISCUSION :}

\section{Diversity of medicinal plant species}

The different types of plant species used by the traditional healers are shown in Table 1with the families, scientific and local name arranged in alphabetical order. In addition, the botanical and local name , families, part used method of preparation, administration route, and ailments treated are stated for each species. Table 1

The present study shows that the rural people are properly versed in nature and the natural resources in their environment. These people in a bid to get rid of various maternal 


\section{Ethnobotany Survey of Medicinal Plants Used for Traditional Maternal Healthcare by Serawai Tribe, Seluma District, Bengkulu - Indonesia

healthcare problem such as menstrual problems, conception or excessive bleeding, etc. depend on plant product . It was also discovered that approximately 52 species of plants have been used by the local communities to treat various illnesses associated with maternal health care.

A total of 52 medicinal plant species belonging to 45 genera and 33 families were used by the local communities to treat various illnesses associated with maternal health care in the Serawai tribe. Zingiberaceae (7 species), Euphorbiaceae, and Poaceae ( 3 species), while most of the families (32) are represented by two or one species, as shown in Figure 2. According to Ramana 2008, scientific studies conducted on the families of these plant provide insights into their rich phytoconstituents and pharmacological actions of the active compounds they possess [12]. The dominance of these families is mainly due to some special properties, such as secondary metabolites. This illustration was observed with some differences discovered in other ethnomedicinal surveys conducted in other regions of the country $[13,14]$ or worldwide [15]

The life form of medicinal plants which treat maternal illness

The life form analysis of medicinal plants showed that herb constitute the highest proportion as shown by 22 species $(42.3 \%)$, however trees were represented by 13 species (25\%), while shrubs were depicted by 10 species $(19.2 \%)$ and climbers were showed by 6 species (11.5\%). Figure 3

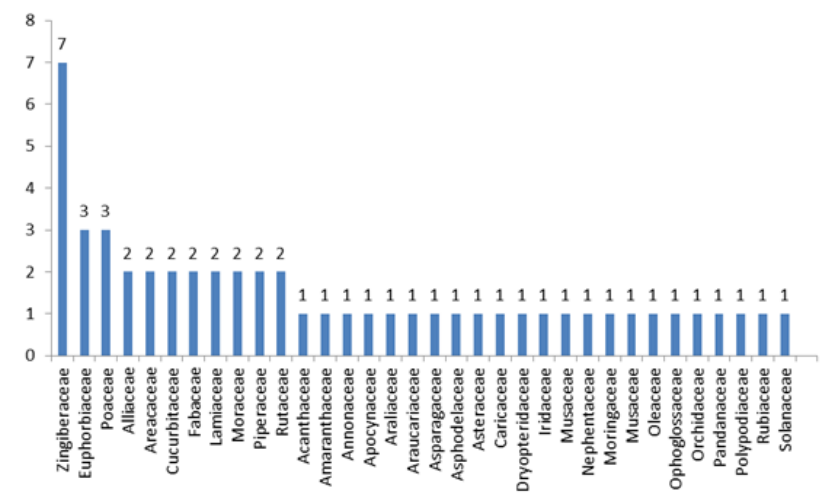

Figure 2. Distributionof plant families for traditional maternal health care in the Serawai tribe, Bengkulu

This study shows that the most represented life forms of medicinal plants in the study area were herbs followed by tree. The trend of using more herbaceous plants tends to be more advantageous as it is easier to cultivate it when they are in short supply. Naturally, there are more herbaceous plant species as compared to trees. Subsequently herbs were the most frequently used plant categories [16, 17]

Plant parts used for traditional maternal health care in Searawai tribe, Bengkulu

The inhabitants of the study area harvest different plant parts for the preparation of traditional remedies e.g. leaves, rhizome, stem, root, fruits, etc. It was discovered that 26 species $(50.9 \%)$ of plants were harvested for their leaves, 5 species $(9,8 \%)$ for rhizomes, 4 species $(7,8 \%)$ for stems and roots, 2 species $(3.9 \%)$ for fruits and bulbs.

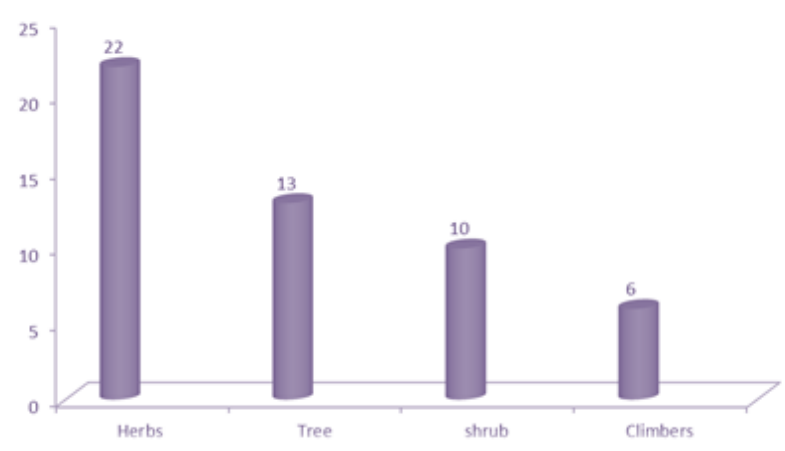

Figure 3. The life form of medicinal plants used fortraditional maternal healthcare in the Serawai tribe, Bengkulu.

However, tuber, bark, seed, flower, sap, and the entire plant constitute the remaining 1 species (1.9\%) Figure 4 . The preference for leaves was because of its easy availability, harvesting, and simplicity in remedy preparation. In addition, they are the center of photochemical reactions, this causes it to be rich in metabolites. Furthermore, it accumulate alkaloids, tannins, and inulins, which are the active components of most herbal preparation [18]. Conversely, similar researches stated that it is a major dominant plant part in Indonesia $[19,20]$ or worldwide $[21-23]^{1,22,23}$ for herbal medicine preparation.

Route of administration of medicinal plants used for traditional maternal health care in Serawai tribe, Bengkulu

The route of administration of these plants is also documented inFigure 5. The most common mode of administration is by drinking. However, the least mode of administration is by eating, with majority administered by drinking $(57.7 \%)$ decoction and juice. These plants are often administered through the dermal (26.9\%), which includes rubbing, topical application on the affected area, and traditional bath wash $[24]$

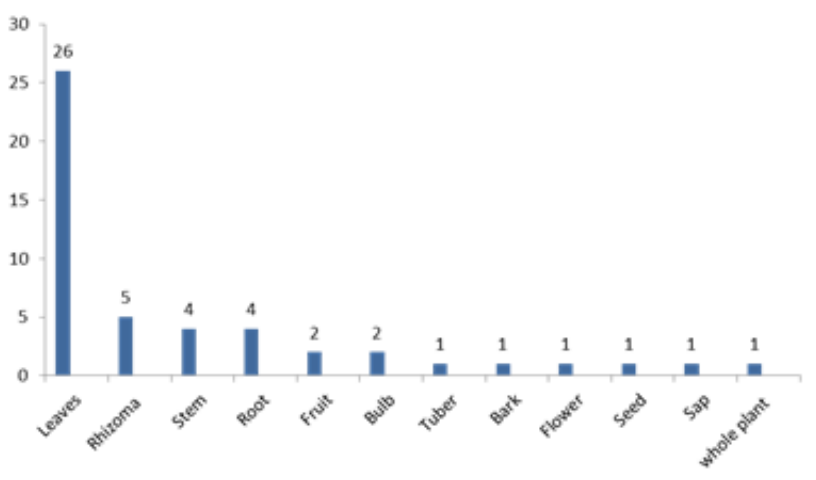

Figure 4. Plant parts used for traditional maternal healthcare in the Serawai tribe, Bengkulu. 
(11.5\%). This is congruent with an ethnobotanical survey conducted in East Kalimantan [25] and Edo State, Nigeria [26] The previous studies stated that the oral intake of decoction was the most common route of administration for the medicinal plant. This involves boiling plant materials for a certain amount of time to soften it and extract its active compound [14]. The predominance of oral administration tends to be explained by a high incidence of internal ailments in the region [27]. On the contrary, it is assumed that the patients mostly accept the oral route.

Most of the plant species are exclusively used for treating diseases, while some are combined to form mixtures, such as Aloe vera, Citrus hystrix, Cymbopogon citratus, Graptophyllum pictum, Luffa acutangula, Musa paradisiaca, and Zingiber officinale because they constitute essential ingredients and they are sometimes used as substitute for others with similar medical properties Table 1 . Its uses are broadly classified to enhance fertility in female and excessive bleeding.

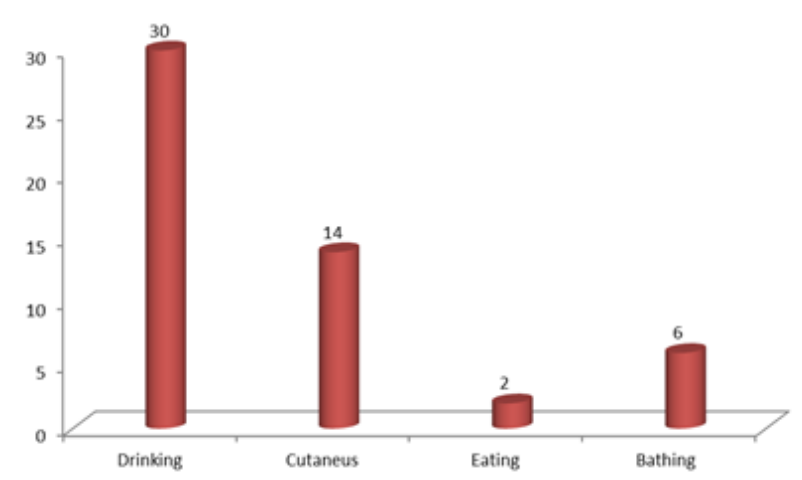

Figure 5. Route of administration of plants used fortraditional maternal health care Serawai tribe, Bengkulu

\section{Maternal health ailment treated by traditional medicinal plants}

The traditional healers identified 16 maternal diseases in the study area Table 1 . The highest number of plants were used to treat excessive bleeding ( 8 plants), boosting stamina after giving birth ( 7 plants), enhance fertility in female ( 5 plants), breast milk enhancement, breast cancer and reduce leucorhea (3 plants each). 2 plants each were used for the treatment of all sort of ovary problem, clearing of uterus after childbirth, promote conception while 1 plant each was used to relieve menstrual cramps, prevent abortion, irregularly in menstral cycle, ovarian cyst and dysnenorhea.

However, most of the medicinal plant species documented are used to treat bleeding. Bleeding is also one of the commonest condition treated with medicinal plants for women in other countries, such as Pakistan ${ }^{[28]}$ and Namibia [29].

The plant materials are sometimes used independently or combined with other parts of the plant. Furthermore, some of the plants were used in the treatment of more than one disease, for example, Curcuma longa L.were used to treat four illnesses. Curcuma alba L. and Drymoglossum piloselloides (L.) C. Presl was each used for the treatment of three diseases. Additionally, similar studies were reported from different part of Indonesia $[14,30]$ or Worldwide.

\section{CONCLUSION:}

In conclusion, traditional medicine remains the primary healthcare system in the Serawai tribe, Bengkulu. Many plant species are used for maternal healthcare. Unfortunately, the practice of medicinal plants by the Serawai tribe is still not adequately documented. There was severe depletion of conventional medicine knowledge among the indigenes of the study area due to the disinterest of the younger generation. However, it is important to conserve this knowledge by scientifically evaluating the biological activities of the medicinal plants. It is also essential to encourage the inhabitants of the study area to practice the cultivation of these plants because it was reported that they are collected from their surroundings.

\section{Acknowledgment:}

The authors are grateful to the indigenes of the Serawai tribe of Seluma district for their hospitality and kind response to the enquiries concerning medicinal plants. The authors are also grateful to all those that helped during the sampling and identification of the reported plant species.

\section{REFERENCES}

1. Shrestha, P.M., and S.S. Dhillion, 2003. Medicinal plant diversity and use in thre highlands of Dolaka district, Nepal. Journal of Ethnopharmacology., 86: 81-96. DOI: 10.1016/ s0378-8741(03)00051-5; PMID 12686446.

2. Ministry of Health Republic of Indonesia 2017. State of Health inequality Indonesia. WHO Document Production Services, Geneva, Switzerland.

3. Candraningrum, D., A. Badawi and A.I.R., Hunga, 2015. A Scoping study inter linkages between women's RHR \& climate change mainstreaimng policy in central Java, Indonesia. Jurnal Perempuan Press, Jakarta. 47 p. (In Indonesian). 4. Mahyar, U.W., J.S. Burley, C. Gyllenhall and D.D., Soejarto, 1991. Medicinal plant of Seberida (Riau Province, Sumatra, Indonesia). Journal ot Ethnopharmacology. 31 : 217-237. DOI: 10.1016/0378-874(91)90007-z; PMID 2023430.

5. Hays, J., 2008. Dukun and traditional medicine in Indonesia. Factanddetails.com/

Indonesia/Education-Health-Energy-Transportation/sub6_6b/.

6. Nadembaga, P., J.I. Boussim, J.B. Nikiema, F. Poli and F, Antognoni 2011. Medicinal plants in Baskoure, Kourittenga Province, Burkana Faso: an ethnobotanical study. J Ethnopharmacol. 133: 378-395. DOI: 10.1016/j.jep.2010.10.010; PMID 20950680.

7. Asase, A., T. Kokubun, R.J Gayer, G. Kite, M.S.J.Simmonds, A.A. Oteng-Yeboahand and G.T. Odamten, 2008. Chemical constituents and antimicrobial activity of medicinal plants from Ghana: Cassia siberiana, HaematOstaphis barteri, Mitragyna inermis and Pseudocedrela kotschyi. Phytotherapy Research. 22 : 1013-1016.

8. Badan Meteorologi, Klimatologi dan Geofisika 2019. Prakiraan cuaca.

http://www.bmkg.go.id/cuaca/prakiraan-cuaca.bmkg? Area ID = $501184 \&$ Prov $=5$. 


\section{Ethnobotany Survey of Medicinal Plants Used for Traditional Maternal Healthcare by Serawai Tribe, Seluma District, Bengkulu - Indonesia

9. Dihamri 2016. Kearifan lokal Suku Serawai Di Kabupaten Bengkulu Selatan. Jurnal Georafflesia. 1(2): 82-92. ISSN 2615-4781. Available at: <https://journals.unihaz.ac.id/index.php/georafflesia/article/view/151>. Date accessed: 04 apr. 2020.

10. Millar, D. \& B. Havenkort 2006. African knowledge and science : Exploring the ways of knowing in Sub-Saharan Africa. In: African knowledges and sciences. University of Ghana, 23-29 October 2206. Barneveld, The Netherland, pp: 11-37.

11. Martin, G.J., 1995. Ethnobotany: A method manual. 1st Edn, Springer US.

12. Ramana, M.V., 2008. Ethnomedicinal and ethnoveterinary plants from Boath, Adilabad district, Andhra Pradesh, India. Ethnobotanical Leaflets, 12: 391-400.

13. Ratnasari, D., S.M. Kartikawati and Muflihati 2017. Tumbuhan obat khusus kesehatan reproduksi wanita di dusun Kayu Baong, Desa Pekawai, Kecamatan Sayan, Kabupaten Melawi. Jurnal Hutan Lestari 5: 499-507.

14. Falah, F. and N. Hadiwibowo, 2017. Spesies identification of traditional medicine plants for womwn's health in East Kalimantan: Lesson learned from local wisdom. Indonesian Journal of Forestry Research. 4: 49-67. DOI : 10.20886/ifjr.2017.4.1.49-68.

15. Kankara, S.S., M.H. Ibrahim, M. Mustafa and R. Go, 2015 Ethnobotanical survey of medicinal plants used for traditional maternal health care in Katsina State, Nigeria. S Afr J Bot. 97: 165-175. DOI : 10.1016/j.sajb2015.01.007.

16. Nalumansi, P.A., M. Kamatenesi-Mugisha and G. Anywar, 2017. Medicinal plants used during alternatif care by pregnant women in Eastern Uganda. Afr J Reprod Health. 21 : 33-44. DOI : 29063/ajrh2017/ v21i4.4; PMID 29624949

17. Asmare, T.W., B.A. Yilkal, T. Mekuannint and A.T. Yibeltal, 2018 Traditional medicinal plants used to treat maternal and child health illnesses in Ethiopia: An -ethnobotanical approach. J Tradit.Med.Clin. Natur., 7:727. DOI:10.417212573-4555.1000277.

18. Focho, D.A., E.A.P. Nkeng, C.F.Lucha, W.T. Ndam and A. Afegenui, 2009. Ethnobotanical survey of plants used to treat diseases of the reproductivr system and preliminary phytochemical screening of some species of Malvaceae in Ndop Central sub-division Cameroon. J.Med.Plant.Res. 3: 301-314. Available online at

http://www.academicjournals.org/JMPR ISSN 1996-0875@ 2009 Academic Journals.

19. Malini, D.M., Madikah, J. Kusmoro, F. Kamilawati and J. Iskandar 2017. Ethnobotanical study of medicinal plants in Karangwangi, District of Cianjur, West Java. Biosaintifika, Journal of Biology and Biology Education. 9 : 345-356.DOI : 10.15294/biosaintifika.v9i2.5756.

20. Putri, L.S.E., Dasumiati, Kristiyanto, Mardiansyah, C. Malik, L.P. Leuvinadrie and E.A. Mulyono, 2016. Ethnobotanical study of herbal medicine in Ranggawulung urban forest, Subang district, West Java, Indonesia. Biodiversitas. 17 : 172-176. DOI: 10.1305/biodiv/d170125. 21. Faruque, M.O., S.B Uddin, J.W. Barlow, S. Hu, S. Dong, Q. Lai, X. Li and X. Hu, 2018. Quantitative ethnobotany of medicinal plants used by indigenous communities in the Bandarban district of Bangladesh. Front Pharmacol. 9:40. DOI:10.3389/fphar.2018.00040; PMID 29467652. 22. Tantengco, O.A.G., M.L.C. Condes, H.H.T. Estadita and E.M. Ragragio, 2018. Ethnobotanical survey of medicinal plants used by Ayta communities in Dinalupihan, Bataan, Philippines. Pharmacog J. 10 : 859-870. DOI: $10.5530 /$ pj.2018.5.145.

23. Umair, M., M.Altaf and A.M. Abbasi, 2017. An ethnobotany survey of indigenous medicinal plants in Hafizabad district, Punjab, Pakistan. Plos One. 12 : e0177912. https://doi.org/10.1371/journal.pone.0177912 24. Falah. F., Noorcahyati and T. Sayektiningsih, 2013. Diversity and utilization of medicinal plants by local community around Gunung Beratus protection forest, East Kalimantan. Journal of Natural Forest. 10: 1-18. DOI : 10.20886/ijfr2017.4.1.49-68.

25. Ogwu, M.C., M.E. Osawaru and G.E. Obahiagbon, 2017. Ethnobotanical survey of medicinal plants used for traditional reproductive care by Usen people of Edo State, Nigeria. Malaya Journal of Biosciences. 4: 17-29.
26. Polat, R., and F. Satil, 2012. An ethnobotanical survey of medicinal plants in Edremit Gulf (Balikesir - Turkey). Journal of Ethnopharmacology. 139: 626-641. DOI : 10.1016/j.jep.2011.12.004; PMID22193175.

27. Hussain,W., M. Ullah, G. Dastagir and L. Badshah, 2018. Quantitative ethnobotanical appraisal of medicinal plantused by inhabitants of lower Kurram, Kurram agency, Pakistan. Avicenna J Phytomed. 8: 313-329. 28. Cheikhyoussef, A., M. Shapi, K. Matengu and H.M. Ashekele 2011. Ethnobotanical study of indigenous knowledge on medicinal plant used by traditional healers in Oshikoto region,Namibia. DOI : 10.1186/1746-4269-7-10; PMID 21388534.

29. Nuraeni, H. and Y.Rustaman 2019. Traditional knowledge of medicinal plants for health of women in Cibodas village Lembang Subdistrict West Bandung Regency and their potency to development of biodiversity education. J. Phys : Conf. Series 1157:022115. doi:10.108811742.6596/1157/2/022115.

30. Kankara, S.S., M.H. Ibrahim, M. Mustafa and R. Go, 2015. Ethnobotanical survey of medicinal plants used for traditional maternal health care in Katsina State, Nigeria. S Afr J Bot. 97: 165-175. 
Table 1. Different types of plant species used fortraditional maternal health care in the Serawai tribe, Bengkulu

\begin{tabular}{|c|c|c|c|c|c|c|}
\hline No & Family & Scientific name & Local name & $\begin{array}{l}\text { Habit/ } \\
\text { domestication }\end{array}$ & Part used/Preparation & Condition managed \\
\hline 1 & Acanthaceae & $\begin{array}{l}\text { Graptophyllum pictum (L.) } \\
\text { Griff }\end{array}$ & Puding abang & Shrub/cultivated & $\begin{array}{l}\text { Mix the leaves with palm } \\
\text { sugar, rhizome of ginger } \\
\text { and boil with } 5 \text { glasses of } \\
\text { water. It is taken orally }\end{array}$ & $\begin{array}{l}\text { Excessive bleeding } \\
\text { after child birth }\end{array}$ \\
\hline \multirow[t]{2}{*}{2} & Alliaceae. & Allium cepa $\mathrm{L}$. & Bawang abang & Herb/cultivated & $\begin{array}{l}\text { Pound the fresh part of } \\
\text { the bulb, add some water } \\
\text { and apply on the vagina }\end{array}$ & $\begin{array}{l}\text { For the treatment of } \\
\text { all sorts of ovary } \\
\text { problems }\end{array}$ \\
\hline & & Allium sativum $\mathrm{L}$. & Bawang putih & Herb/ cultivated & $\begin{array}{l}2-4 \text { bulbs consumed } \\
\text { directly }\end{array}$ & Ease labor \\
\hline 3 & Amaranthaceae & Celosia argentea $\mathrm{L}$ & Bungo abang & Herb/ cultivated & $\begin{array}{l}\text { Stem is boiled in water } \\
\text { and taken orally }\end{array}$ & $\begin{array}{l}\text { Clears the uterus } \\
\text { after child birth }\end{array}$ \\
\hline 4 & Annonaceae & Annona muricata L. & Srikayo & Herb/ cultivated & $\begin{array}{l}\text { Leaves is boiled in } \\
\text { water and taken orally }\end{array}$ & $\begin{array}{l}\text { Breat cancer, } \\
\text { relieves menstrual } \\
\text { cramps }\end{array}$ \\
\hline 5 & Apocynaceae & Alstonia scholaris (L.) R.Br. & Pulai & Tree/wild & $\begin{array}{l}\text { Leaves is boiled in one } \\
\text { glass of water, and taken } \\
\text { while still warm }\end{array}$ & $\begin{array}{l}\text { Clears uterus and } \\
\text { excessive uterine } \\
\text { bleeding after child } \\
\text { birth. }\end{array}$ \\
\hline \multirow[t]{2}{*}{6} & Arecaceae & Areca catechu $\mathrm{L}$. & Pinang & Tree/wild & $\begin{array}{l}\text { Seed is crush and boiled } \\
\text { in water. It is used for } \\
\text { bathing after child birth }\end{array}$ & Gives stamina \\
\hline & & Cocos nucifera $L$. & Tempuruk niur & Tree/cultivated & $\begin{array}{l}\text { Burn the young coconut } \\
\text { shell, and sit on it while } \\
\text { it's still warm }\end{array}$ & $\begin{array}{l}\text { Excessive uterine } \\
\text { bleeding after } \\
\text { childbirth }\end{array}$ \\
\hline 7 & Araliaceae & Nothopanax Scutellarium Merr. & Mangkokan & Shrub/cultivated & $\begin{array}{l}\text { Grind the leaves, add } \\
\text { some water and take it } \\
\text { orally }\end{array}$ & Reduces leucorrhea \\
\hline 8 & Araucariaceae & Agathis alba (Lam.) Foxw. & Damar & Tree/wild & $\begin{array}{l}\text { Sap of the wood is burnt } \\
\text { and applied on the vagina }\end{array}$ & Promotes conception \\
\hline 9 & Asparagaceae & $\begin{array}{l}\text { Cordyline fruticosa (L.) A. } \\
\text { Chev. }\end{array}$ & Juang & Shrub/cultivated & $\begin{array}{l}\text { The root is boiled in } \\
\text { water and taken orally }\end{array}$ & Prevents abortion \\
\hline 10 & Asphodelaceae & Aloe vera (L.) Burm. F. & Lidah buaya & Herb/cultivated & $\begin{array}{l}\text { Pound the leaves and } \mathrm{mix} \\
\text { with the tip of } 100 \mathrm{~m} \text { gr of } \\
\text { a young stem of Musa } \\
\text { paradisiaca and add ten } \\
\text { leaves of Cyclea barbata. } \\
\text { It is applied to the } \\
\text { stomach for } 3 \text { days }\end{array}$ & $\begin{array}{l}\text { Enhances fertility in } \\
\text { females }\end{array}$ \\
\hline 11 & Asteraceae & Ageratum conyzoides L. & Bondotan & Herb/wild & $\begin{array}{l}\text { The fresh part of the } \\
\text { leaves is pounded and } \\
\text { applied on the vagina }\end{array}$ & $\begin{array}{l}\text { Excessive uterine } \\
\text { bleeding after } \\
\text { childbirth, uterine } \\
\text { tumor }\end{array}$ \\
\hline 12 & Caricaceae & Carica papaya L. & Sensilo & Tree/cultivated & $\begin{array}{l}\text { Leaves is boiled in water } \\
\text { and taken orally }\end{array}$ & Gives stamina \\
\hline \multirow[t]{2}{*}{13} & Cucurbitaceae & $\begin{array}{l}\text { Benincasa hispida (Thunb.) } \\
\text { Cogn. }\end{array}$ & Daun kundur & Liana/cultivated & $\begin{array}{l}\text { Squeeze the leaves and } \\
\text { add some water. Rubbed } \\
\text { on the chest }\end{array}$ & $\begin{array}{l}\text { Breast milk } \\
\text { enhancement }\end{array}$ \\
\hline & & Luffa acutangula (L.) Roxb. & Timput & Liana/cultivated & $\begin{array}{l}\text { Leaves are pounded and } \\
\text { mixed with leaves of } \\
\text { Momordica charantia. } \\
\text { Rubbed on the stomach }\end{array}$ & $\begin{array}{l}\text { Enhances fertility in } \\
\text { female }\end{array}$ \\
\hline 14 & Dryopteridaceae & $\begin{array}{l}\text { Polystichum setiferum (Forssk.) } \\
\text { Moore ex Woyn }\end{array}$ & Paku lempiding & Shrub/wild & $\begin{array}{l}\text { Leaves are boiled in } \\
\text { water and taken orally }\end{array}$ & Gives stamina \\
\hline \multirow[t]{3}{*}{15} & Euphorbiaceae & Manihot esculenta Crantz & Bekayu & Shrub/cultivated & $\begin{array}{l}\text { The tuber is boiled, } \\
\text { fermented and taken } \\
\text { orally }\end{array}$ & $\begin{array}{l}\text { Irregularities in the } \\
\text { menstrual cycle }\end{array}$ \\
\hline & & Phyllanthus urinaria L. & Meniran & Herb/cultivated & $\begin{array}{l}\text { Leaves are pounded and } \\
\text { applied to the affected } \\
\text { area }\end{array}$ & Reduces Leucorrhea \\
\hline & & Sauropus androgynus (L.) Merr. & Katu & Shrub/cultivated & $\begin{array}{l}\text { Young leaves are cooked } \\
\text { and taken orally }\end{array}$ & $\begin{array}{l}\text { Breast milk } \\
\text { enhancement }\end{array}$ \\
\hline \multirow[t]{2}{*}{16} & Fabaceae & Cassia alata L. & Gelinggang & Tree/cultivated & $\begin{array}{l}\text { Leaves are heated on fire } \\
\text { until withered and } \\
\text { applied on the vagina }\end{array}$ & $\begin{array}{l}\text { Excessive uterine } \\
\text { bleeding after } \\
\text { childbirth }\end{array}$ \\
\hline & & Tamarindus indica $\mathrm{L}$. & Asam Jawa & Tree/wild & $\begin{array}{l}\text { The flower is grinded and } \\
\text { taken orally }\end{array}$ & $\begin{array}{l}\text { Enhances fertility in } \\
\text { female }\end{array}$ \\
\hline 17 & Iridaceae & $\begin{array}{l}\text { Eleutherine palmifolia (L.) } \\
\text { Merr. }\end{array}$ & Bawang sabrang & Herb/ cultivated & $\begin{array}{l}\text { Grind the leaves, add } \\
\text { some water and take } \\
\text { orally }\end{array}$ & Ovarian cysts \\
\hline \multirow[t]{2}{*}{18} & Lamiaceae & Vitex pinnata $\mathrm{L}$. & Leban & Tree/wild & $\begin{array}{l}\text { Leaves are boiled in } \\
\text { water and taken orally }\end{array}$ & $\begin{array}{l}\text { Excessive uterine } \\
\text { bleeding after } \\
\text { childbirth }\end{array}$ \\
\hline & & Ocimum tenuiflorum $\mathrm{L}$. & Rehuku & Herb/cultivated & $\begin{array}{l}\text { The root is cut into small } \\
\text { pieces and mixed with } \\
\text { roots of Coix lacryma- } \\
\text { jobi, } \\
\text { Saccharum officinarum, } \\
\text { and red Celosia argentea. } \\
\text { Add some water and boil } \\
\text { in young bamboo. It is } \\
\text { taken orally }\end{array}$ & $\begin{array}{l}\text { Excessive uterine } \\
\text { bleeding after } \\
\text { childbirth }\end{array}$ \\
\hline
\end{tabular}




\section{Ficus septica Burm. F.}

Awar-awar

Tree/wild

20 Moringaceae

Moringa oleifera Lam.

21 Musaceae
Daun kelor

Pisang kepok
Tree/cultivated

Herb/cultivated

The root is cut off and soaked in bottled water for a night. It is taken Orally

Leaves are pounded and applied to the affected area

Enhances fertility in female

For the treatment of all kinds of ovarian problems

Grind the tip of the young Enhances fertility in stem, $\operatorname{mix}$ with leaves of female Aloe vera and

Cyclea barbata. It is usually rubbed on the stomach

$\begin{array}{llll}22 & \text { Nepenthaceae } & \text { Nepenthes kuchingensis Kurata } & \text { Kantong semar } \\ 23 & \text { Oleaceae } & \text { Jasminum sambac (L.) Aiton } & \text { Melati } \\ 24 & \text { Ophioglossaceae } & \begin{array}{l}\text { Helminthostachys zeylanica (L.) } \\ \text { Hook }\end{array} & \text { Jajalakan } \\ 25 & \text { Orchidaceae } & \begin{array}{l}\text { Cymbidium } \\ \text { finlaysonianum Lindl. } \\ \text { Pandanus amaryllifolius Roxb. }\end{array} & \text { Pandan } \\ & \text { Pandanaceae } & \text { Simbae buah }\end{array}$

Liana/wild

The whole plant is boiled in water and taken orally

Shrub/cultivated Flower is boiled in water and taken orally

Herb/cultivated Leaves are boiled in water and taken orally

Herb/cultivated Leaves are boiled in water and taken orally

Herb/cultivated $\quad$ Boil the leaves and add cold water. It is used for bathing after childbirth

\begin{tabular}{llll}
\hline 27 & Piperaceae & Piper betle L. & Sighia \\
& Piper nigrum L. & Saang \\
28 & Poaceae & $\begin{array}{l}\text { Cymbopogon citratus (DC.) } \\
\text { Stapf. }\end{array}$ & Seghai
\end{tabular}

29 Polypodiaceae

30 Rubiaceae

31 Rutaceae

32 Solananceae

33 Zingiberaceae.
Solanum torvum Sw.

Alpinia galanga (L.) Willd.

Alpinia malaccensis (Burm.f). Roscoe

Curcuma alba $L$

Curcuma aurantiaca Zijp.

Curcuma longa L
Limau

Swingle

Citrus hystrix DC

Jeruk purut

Liana/cultivated
Liana/cultivated

eaves are boiled in water and taken orally

Boil the leaves and add cold water. It is used for bathing after childbirth

Herb/cultivated Mix the stem with 5 leaves of Citrus hystrix, Alpinia galangal, rhizome of Curcuma longa, and boil Add cold water, used for bathing after childbirth.

The root is boiled in water and taken orally

Shrub/cultivated The stem is squeezed and taken orally

Liana/wild

Leaves are boiled in water and taken orally

Shrub/cultivated

Bark is boiled in water and taken, while the fruit is shredded and rubbed on the chest

Tree/cultivated The fruit is squeezed and taken

Tree/cultivated aken together with the leaves of C. longa, A. Galanga and the stem of $C$.

Citratus. Coldwater is added and used for bathing after childbirth

Shrub/cultivated Fruits are consumed directly

Terong pipit

Lengkuas

Herb/cultivated

Young rhizome is chewed and then sprayed on the affected area Leaves are boiled in water and taken orally

Kunyit putih

Temu blobo

Herb/cultivated

Pound rizome, add some water and take orally

Herb/cultivated Rhizome is shredded squeezed, and taken orally

Kunyit kuning
Herb/cultivated
Pound rhizome, add some water and take orally
Breast milk enhancement Relieves menstrual cramps

Breast cancer

Gives stamina Reduces Leucorrhea

Gives stamin

Gives stamina

Excessive uterine bleeding after childbirth

Relieves menstrual pain

Breast cancer, leucorrhea and excessive uterine bleeding after childbirth

Breast cancer

Dysmenorrhea

Gives stamina

Relieves menstrual pain

Excessive uterine bleeding after childbirth Leucorrhea, breast and cervical cancer Cervical cancer

Reduce Leucorrhea, irregular menstruation, inflammation and relieves menstrual pain

Breast milk enhancement 
and Syzygium

aromaticum leaves, add

some cold water. It is

used for bathing after

childbirth. 